
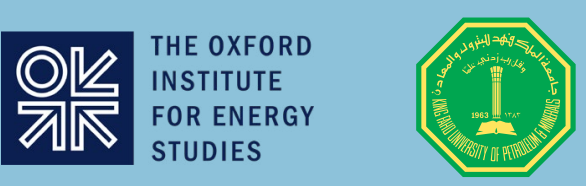

\title{
Will Shale Impede or Accelerate the Global Energy Transition?
}




\section{About KAPSARC}

The King Abdullah Petroleum Studies and Research Center (KAPSARC) is a non-profit global institution dedicated to independent research into energy economics, policy, technology and the environment across all types of energy. KAPSARC's mandate is to advance the understanding of energy challenges and opportunities facing the world today and tomorrow, through unbiased, independent, and high-caliber research for the benefit of society. KAPSARC is located in Riyadh, Saudi Arabia.

This publication is also available in Arabic.

\section{Legal Notice}

(C) Copyright 2021 King Abdullah Petroleum Studies and Research Center ("KAPSARC"). This Document (and any information, data or materials contained therein) (the "Document") shall not be used without the proper attribution to KAPSARC. The Document shall not be reproduced, in whole or in part, without the written permission of KAPSARC. KAPSARC makes no warranty, representation or undertaking whether expressed or implied, nor does it assume any legal liability, whether direct or indirect, or responsibility for the accuracy, completeness, or usefulness of any information that is contained in the Document. Nothing in the Document constitutes or shall be implied to constitute advice, recommendation or option. The views and opinions expressed in this publication are those of the authors and do not necessarily reflect the official views or position of KAPSARC. 


\section{Key Points}

$\mathrm{U}$ nited States (U.S.) shale has transformed oil market dynamics in ways we never thought possible. Shale oil has transformed the oil supply curve through massive supply shocks, such as the rapid increase in tight oil production over the past decade, alongside productivity and technology developments.

The uncertainty wrought by the repercussions of the COVID-19 pandemic has disrupted supply/demand balances. As the world endeavors to return to normality, the energy landscape has changed, and the outlook for shale oil demand reaching pre-pandemic levels is mixed.

The discussion about shale is opportune, especially in the current context of the transition to cleaner energy resources. This transition is moving traditional oil-related funds into alternative investments, reducing the attractiveness of shale oil for investors.

During the workshop, Would Shale Impede or Accelerate the Global Energy Transition?, participants provided meaningful insights about future shale developments.

Key takeaways and points addressed in the workshop were as follows:

\section{U.S. Shale and the global oil market}

Global oil demand contracted between 8 and 10 million barrels per day during the second quarter of 2020 . At the same time, oil demand recovery has been slower than expected, resulting in downward revisions to oil demand for almost every month between 2020 and 2022. It may take longer for demand to go back to pre-pandemic levels. It is currently envisaged to return to pre-pandemic levels by mid-to-end of 2022.

Shale production rebounded promptly following the collapse of oil prices in 2014 . The factors at play in this cycle, namely capital availability, political sentiment, and regulatory concerns, are different, but the rock is not. The shale deposits are easier to extract given technological advancements. This is a very resilient industry.

By holding monthly Joint Ministerial Monitoring Committee meetings, and introducing and implementing a compensation regime as an additional tool to ensure high compliance, OPEC+ has sent a very credible signal to the oil market. Without collective action and high compliance of OPEC+, the oil market would take longer to rebalance.

The transition from fossil fuels to renewables may take longer than expected. Hydrocarbons will continue to share a significant part of the energy mix for quite some time, and as such, tight oil (or shale gas) will play major roles in meeting global energy demand. 


\section{Market structure and shale investments}

Shale operators are feeling more confident about the current price levels of $\$ 60+$ oil. However, the focus of producers is on breakeven costs, suggesting a lack of absolute volume growth in the U.S. The pessimistic sentiment around the oil and gas market, the experience of the price crisis in April 2020 , and the pressure on curbing fossil fuel usage from the new U.S. administration will hamper the optimism and potential growth of the shale oil industry.

Finding the balance between value creation and growth during these difficult times is not easy. Obviously, capital discipline will be more important than before. Operators will be obliged to tap the brakes on production growth and focus more on value creation. Henceforth, shale investors are moving away from the old industry model of high investment and limited free cash flow (FCF) generation to make more conservative investments, similar to those of big oil companies worldwide, and will moderate the shale production growth rates in the future.

More bankruptcy filings in the shale sector are yet to come. Their frequency and size will increase. Investor pressure on operators will also increase.

Most of the development in the shale industry will be driven by a handful of large tight oil producers, especially in the Permian Basin, increasing their presence through mergers and acquisitions.

The larger shale oil companies have become highly efficient and are likely to adapt to an environment of tighter environmental regulations, especially if carbon is priced adequately.

\section{Technological innovation in the shale sector}

The faster drilling of longer lateral wells has meaningful implications across the board. Technological developments now allow producers to drill slightly longer laterals and to keep productivity flat in terms of barrels per foot, resulting in higher production rates per well.

More technological innovation is underway to address some of the existing and emerging problems in the shale sector, including land-use footprint, gas flaring and venting, volumes of water usage, disposal of wastewater, and water contamination. The year 2020 led to major structural improvements in the shale sector driven by the industry's falling capital expenditure (capex) and operating expenses (opex). This seems to have helped accelerate the deployment of machine learning and artificial intelligence as a means of reducing risk and ensuring the success of production and, henceforth, reducing development costs substantially.

Gas flaring levels have declined rapidly, especially in the Permian Basin due to low oil production and the construction of a pipeline network that captures, processes, and transports gas to nearby markets. This decline has helped many companies to reduce their carbon emissions. 
Shale development is no longer confined to the U.S. Technology spillover, easy access to capital, and a favorable regulatory environment have helped national and international oil companies to exploit shale assets in many countries outside the U.S. However, the pace of these projects' development is not as aggressive as those in the U.S., and the former are experiencing different sets of challenges than those in the U.S. 


\section{Background to the Workshop}

$n$ December 9 and 10, 2020, the King Abdullah Petroleum Studies and Research

Center (KAPSARC) welcomed professionals and academics from a wide range of research institutions, the financial sector, the oil and gas industry, and energy consulting firms worldwide to shed light on shale development post-COVID-19.

The workshop, titled Would Shale Impede or Accelerate the Global Energy Transition?, was hosted by KAPSARC in collaboration with the Oxford Institute for Energy Studies (OIES) and King Fahad University of Petroleum and Minerals (KFUPM).

The starting point of the first day's discussion addressed uncertainties in oil supply and demand outlooks, and the role of shale in the energy transition. The panel discussed how policy and regulatory directions proposed by recent demand outlooks would affect oil and gas demand and the shale sector in the short-to-medium term. The panel provided a comprehensive view from the ground of the investment environment in the U.S., the shale oil and gas sector, and how the sector's landscape has changed post-COVID-19. The panel discussed how bankruptcy rules and provisions help many distressed developers to re-enter the market.
On the second day of the session, speakers discussed the potential for shale production outside North America. The session examined the lessons learned from the U.S. shale industry and how they are being customized, especially in the Kingdom of Saudi Arabia's Jafurah field. The speakers also examined the dynamic innovation and the pace of technological adoption in the shale sector. They highlighted how collaboration between the oil and gas sector and academia will foster innovation. 


\section{Background on Shale}

hale is the source rock where hydrocarbons were originally formed before they migrated and became trapped in reservoirs.

Hydrocarbon deposits in these shale formations are known as tight oil or shale gas. These formations are areally and/or vertically extensive, containing significant quantities of oil and gas.

Tight oil comprises high API gravities in the range of 40 to 70 degrees. Because of their high API gravities, many refineries that are accustomed to denser crude have to be retrofitted to accommodate an increased intake of lighter grades. Tight oil makes up $10 \%$ of the world's technically recoverable oil.
The U.S. Energy Information Administration (EIA) estimated that at the end of 2013, North America had 100 billion barrels and 1,740 trillion cubic feet of unproved technically recoverable reserves of oil and gas, respectively (EIA 2015). Tight oil accounted for over $70 \%$ of U.S. oil production in 2019.

In March 2020, the Federal Reserve Bank of Dallas conducted a survey harvesting opinions on what the price of West Texas Intermediate (WTI) would have to be to profitably drill a new well in their basins.

The average response was in the range of $\$ 46-\$ 52$ per barrel (b). Some producers can handle prices as low as $\$ 30 / b$ in the Permian Basin. The price for recovering the operating expenses of existing wells is in the range of $\$ 23 / \mathrm{b}-\$ 36 / \mathrm{b}$ (Figure 1).

Figure 1. Breakeven prices.

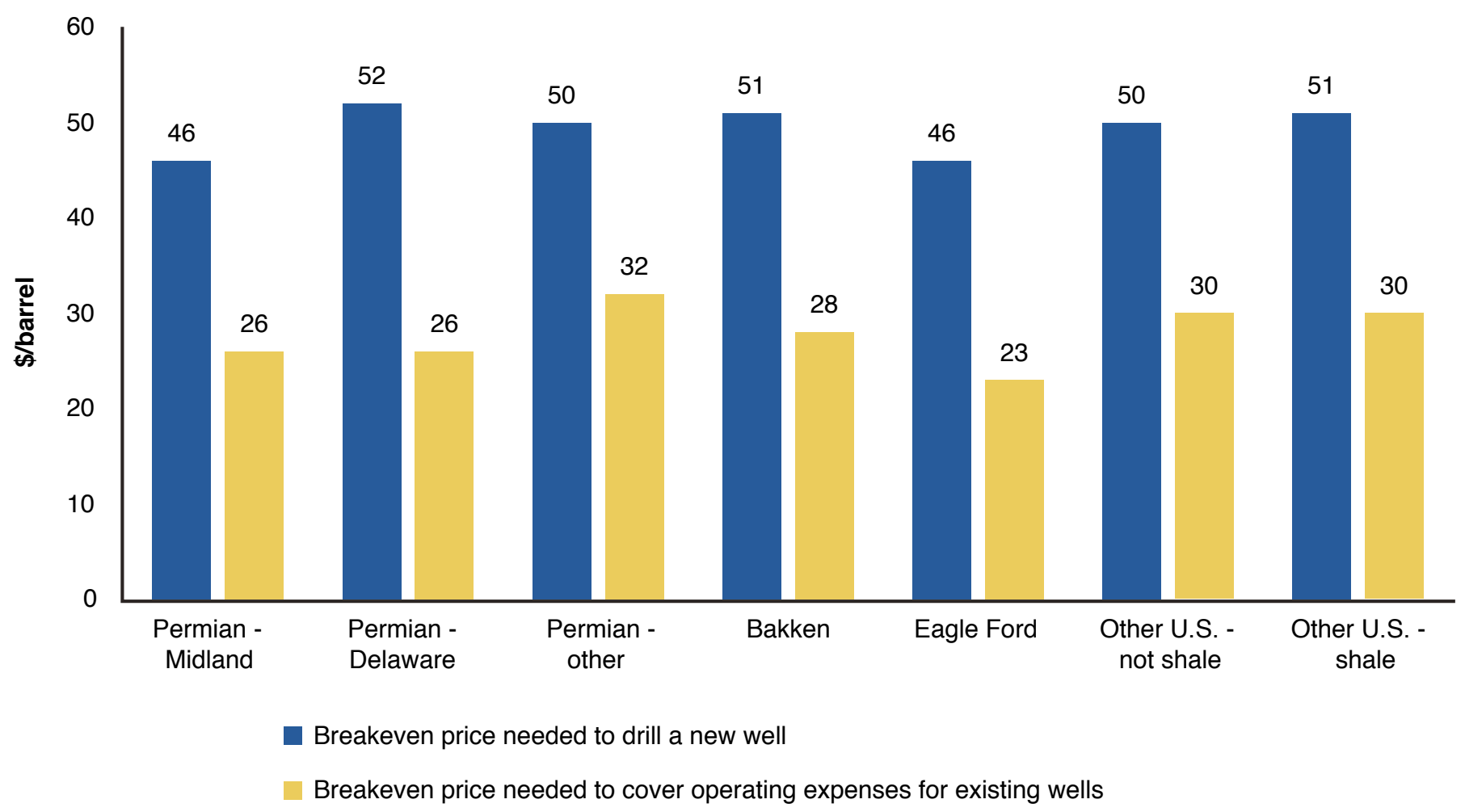

Source: Federal Reserve Bank of Dallas. 
While the deployment of directional drilling and fracking helped to extract these deposits, shale wells suffered from lower well productivity and steeper production decline trends compared with their conventional peers.

Tight oil and shale gas development requires constant investment to maintain production. Many wells had to be drilled and fracked simultaneously to offset the steep production decline, as depicted in Figure 2. Without enough new completions and new drilling, cash flows dry up, and vice versa; and, of course, cash flow depends primarily on high oil and gas prices.

Operators continue to exploit economies of scale and optimize costs across the oil and gas value chain to extract hydrocarbons from shale formations. These improvements are helping to lower overall breakeven oil prices, and shale development is slowly and steadily becoming more competitive globally.

On a different note, much of the discussion about shale development and growth evolved around the Permian Basin. The Permian Basin, situated in West Texas and Southeast New Mexico, is the largest active shale basin in the U.S. and comprises multi-stacked formations. The land above the Permian Basin covers an area of 75 thousand square miles, which is 22 times the area of the land above Saudi Arabia's Ghawar oilfield.

The Permian, labeled a 'dying basin,' was revitalized with significant oil production in the late 2000s from its shale formations and has been under the spotlight ever since.

Much of the success of the Permian's revitalization is attributed to technology spillover from the Bakken

Figure 2. Vintage production of tight oil wells in million barrels per production start year.

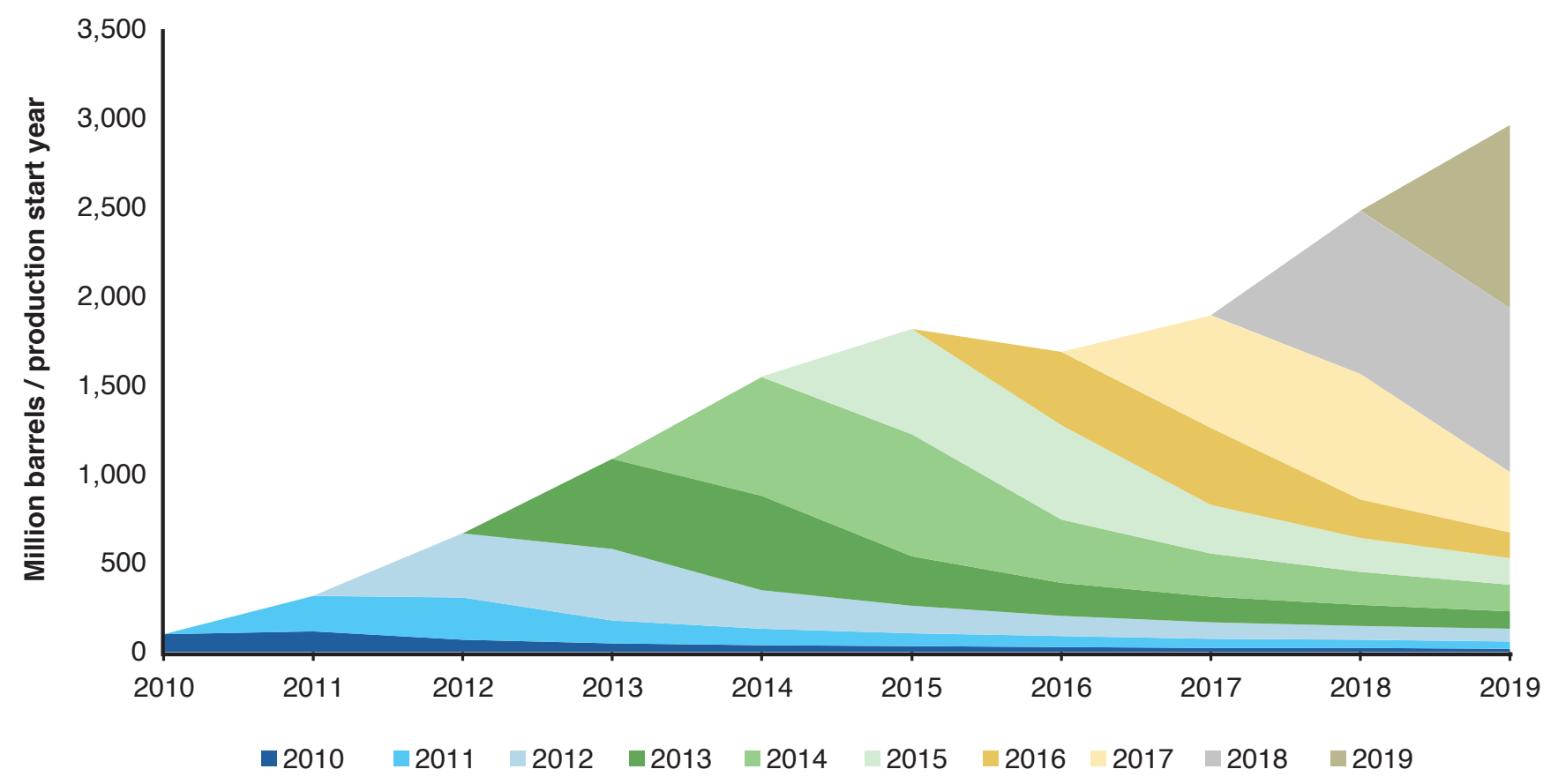

Source: Rystad Energy. 
and other basins, in addition to its proximity to demand centers and existing infrastructure. These factors intrigued many developers, including supermajors such as ExxonMobil and Shell, to enter, buy or lease more acreages in the basin, and acquire small-to-medium size developers in the area to increase their positions. In 2020, Chevron acquired Noble Energy and ConocoPhillips acquired Concho, both of which had large stakes in the Permian. 


\section{The COVID-19 Shock, U.S. Shale, and the Global Oil Market}

o understand the shale industry and its production growth, it is vital to understand the demand destruction caused by the spread of COVID-19, and how OPEC+ adjusted oil production levels to adsorb the excess supply resulting from the demand shock and restore balance to the market.

\section{Demand shock and OPEC+}

The oil demand shock of 2020 was unprecedented. Not only did it vary in size, but it was also uneven across oil products and geographies.

Even if demand for oil regains its pre-pandemic level, oil demand growth may not as it depends on structural changes in consumer behavior and policies imposed by the new U.S. administration (e.g., a ban on fracking oil wells in federal lands, halting the expansion of the Keystone Pipeline, etc.). These factors may impede the growth of U.S. oil and gas production, particularly the shale sector.

The OPEC+ cuts of 2020 were vital in balancing the market. High compliance was also a key feature in 2020, and this will remain key throughout the entirety of the OPEC+ pact to cut supply. Compliance levels were above $100 \%$, even though Iran, Venezuela, and Libya are not part of the deal.

By holding monthly Joint Ministerial Monitoring Committee (JMMC) meetings, and introducing and implementing a compensation regime, as an additional tool to ensure high compliance, OPEC+ sent a very credible signal to the market. Without the collective action of OPEC+ and the group's high compliance, the oil market would take longer to rebalance.

\section{U.S. shale: the supply adjustment mechanism}

When oil prices fell below shale operators' breakeven costs, many tight oil producers temporarily shut-in their legacy wells. At the end of 2019, U.S. tight oil production averaged over 9 million barrels per day (MMb/d) before dropping to an average of 7.26 MMb/d in 2020. However, following the collective actions and increased compliance of OPEC+, oil prices slowly recovered and encouraged many operators to bring their shut-in wells on-stream.

Cost savings appeared to have been largely exhausted, and companies had no option but to slash their capital expenditures in response to the sharp declines in oil prices. Massive production curtailment occurred during April and May 2020 due to storage challenges. However, most production cuts ceased during the summer and production picked up. The number of drilling rigs fell to below 2019 levels in response to cost cuts, and 2020 rig activity was too low to offset production losses.

Before 2020, many operators were building a stock of drilled but uncompleted wells (DUCs) and were waiting for prices to recover before completing them. Operators were compelled to generate and preserve cash flows to help them withstand the low oil price environment, so they fracked and placed their DUCs into production (Figure 3). 
Figure 3. DUCs, and drilled and completed wells in the U.S. shale sector.

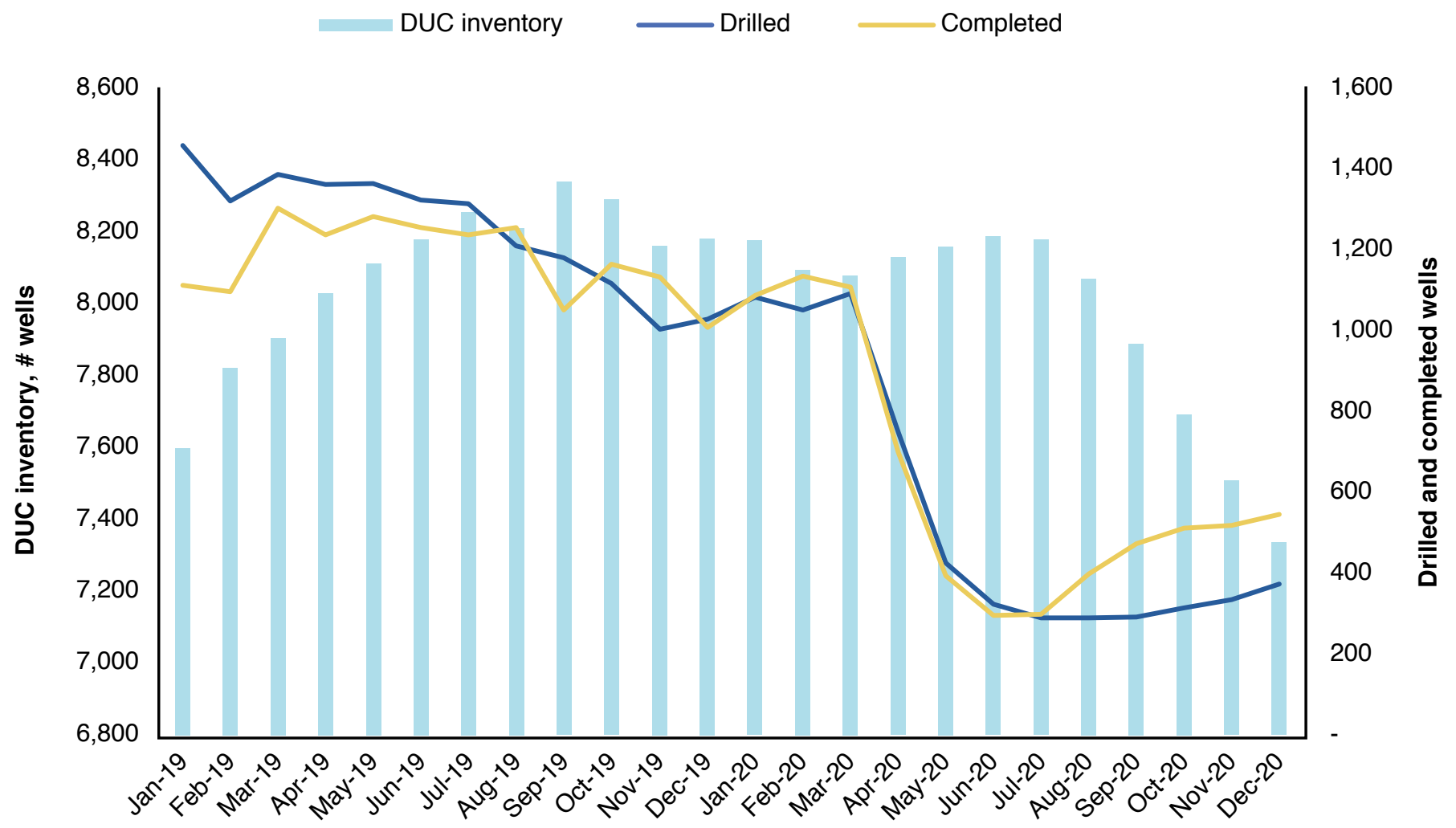

Source: U.S. Energy Information Administration. 


\section{Bankruptcies and Consolidations in the Tight Oil Sector}

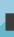

O ver 250 oil and gas operators filed for Chapter 11 protection since January 2015. As of mid-2020, approximately 70 out of these 250 independents had tight oil assets as part of their portfolio when they declared bankruptcy.

While one could argue that this production will be withdrawn from the market, most of the wells have remained in business. Even when operators opt to sell their investments to pay off their withstanding loans, the assets are handed to more efficient operators who choose to produce and generate revenues. In other words, property ownership does not dilute the value of these assets. As a matter of fact, during fire sales, the buyer acquires them on favorable terms.

After emerging from bankruptcy, the average monthly oil production per producer drops by $18 \%$. This means that the oil remaining underground is simply transferred to another 'efficient' operator through sales, who in return will develop them and place them on-stream. Therefore, Chapter 11 provisions and more tight oil production may have led to a saturated market.

\section{The future of distressed tight oil developers}

Following the financial crisis in 2008 , investors poured money into the shale sector. This was one of the drivers of the shale boom. Driven by heightened awareness of climate change and concerns over the shale sector's profitability, there has been a growing interest in and shift into renewables in recent years. COVID-19 will exacerbate this shift. In light of this, the shale sector will find it increasingly difficult to access capital.
Additionally, more bankruptcies are yet to come. Their frequency and debt size will increase, and investor pressure on companies will also mount.

\section{Mergers and acquisitions are gaining traction}

Mergers and acquisitions (M\&As) thrive during low oil price environments, especially when companies are valued below their 'fair price.' The number of $M \& A$ deals in the first half of 2020 was below expectations. The number of M\&As increased following the announcement of Chevron's acquisition of Noble Energy in July 2020. The drivers of this consolidation were Nobel's strong balance sheet and operational excellence in the Permian Basin.

Consolidations have long-term implications, and most shale developments will be driven by a handful of large tight oil producers, especially in the Permian Basin. Shale developers are moving away from the old industry outlook with high investment rates and limited FCF generation to make conservative investments, similar to big oil worldwide, and moderate investment growth rates in the future. 


\section{What Are the Challenges Impeding the Recovery of the U.S. Shale Sector?}

The U.S. oil industry, and the shale sector in particular, is facing challenges and uncertainties. These include low investment in exploration and production, possibly prolonged low oil prices below the breakeven costs of shale wells, and increased pressure from regulators and investors to decarbonize and reduce gas flaring and venting. These factors are obstructing the recovery of tight oil production.

According to the EIA, the U.S. oil industry is responsible for only $6 \%$ of the total U.S. domestic methane emissions. Methane leakages occur during drilling and transporting gas in pipelines. Satellite images are helping to detect these leaks, but it remains difficult to quantify their volumes. To avoid those leakages, the associated gas must be flared for safety reasons instead of venting it freely because of its hazardous nature. Capturing and marketing associated gas is expensive, and small tight oil developers cannot justify the cost of building gas pipelines.

Big shale oil developers flare less because of their large scale. This gives them an advantage in negotiating with pipeline companies to capture gas and transport it to end sales points. These large operators are increasingly minimizing their carbon footprints, as many have set implicit or explicit flaring targets. In recent years, more operators have built pipelines before tying their wells and placing them into production. This has helped to reduce carbon emissions (Figure 4).

Figure 4. Wellhead flaring by oil basin in billion cubic feet.

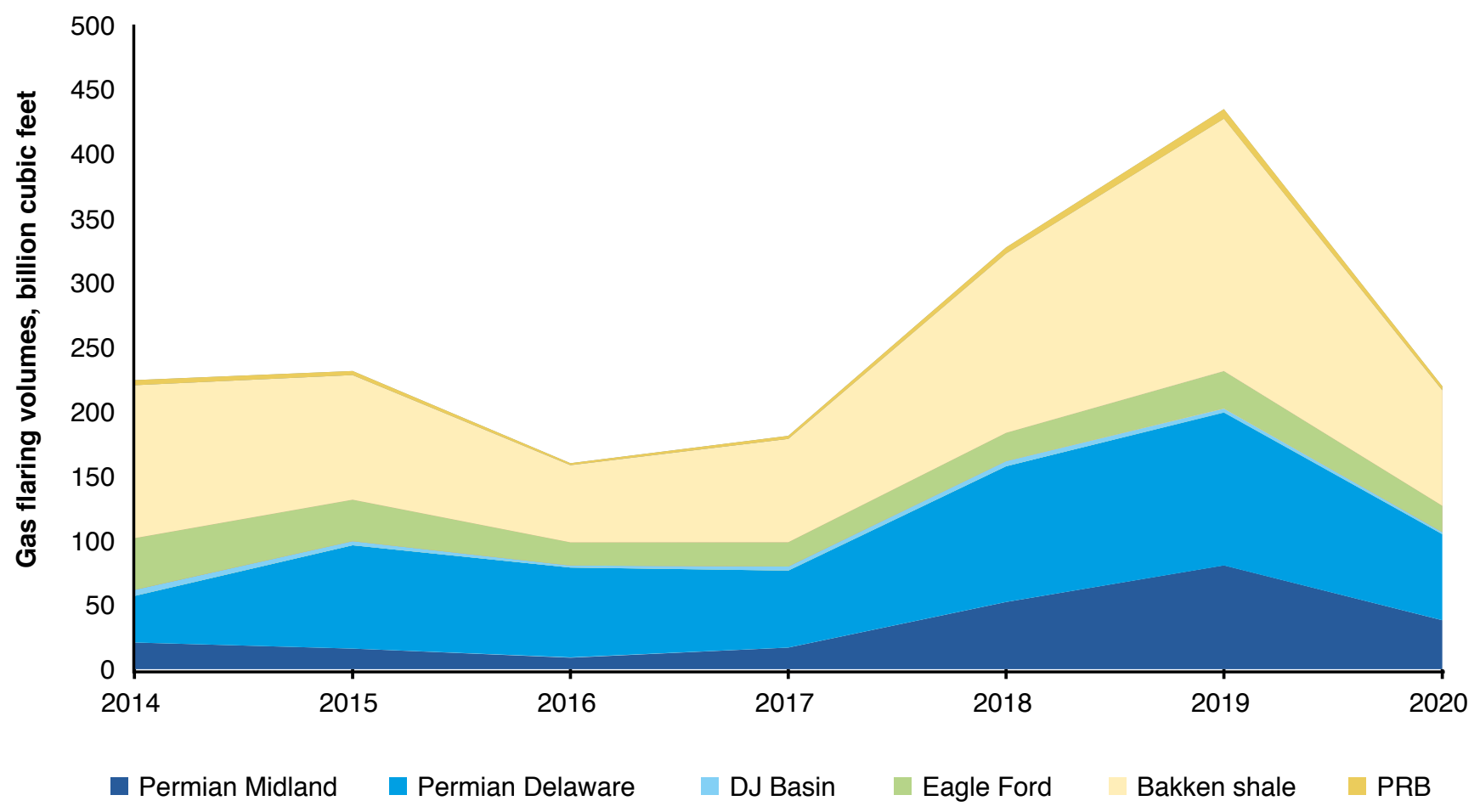

Source: Rystad Energy. 
Carbon capture and sequestration (CCS) is a potential application that large oil companies can use to decarbonize their oil. These companies have unique capabilities and knowledge of geology, which allows them to store carbon dioxide underground in depleted oil reservoirs, saline aquifers, or to use them in enhanced oil recovery applications. Plans are underway for nearly a dozen commercial-scale repositories, mostly along the U.S. Gulf Coast.

A U.S. carbon tax may incentivize more CCS applications.
While regulations are likely to play a role in carbon emissions reduction in the near future, participants believe that the biggest driver behind such a reduction in the shale sector is the investor community, which is increasingly becoming more environmental, social and corporate governance (ESG) focused. 


\section{Can U.S. Shale Surprise to the Upside?}

$\mathbf{R}$ ig activity has rebounded from low levels and stabilized, with the highest specification drilling rigs taking the lead. The monthly counts for rigs drilling new oil and gas wells increased from a low of 248 in August 2020 to 340 in December 2020 (EIA 2021). Nevertheless, rig activity is still too low to offset declines and boost production.

The industry is leveraging DUCs, but the industry should maintain flat production. Over $70 \%$ of the current DUCs should have been spudded in Q2-2020. It may take up to three quarters for the shale sector to bring DUCs back to acceptable levels.
The productivity gains per lateral length and footage fracked are improving. Many U.S. shale basins have not yet reached their inflection points. Operators are still focusing on sweet spots, and there is ongoing optimization on different levels.

Global oil demand contracted between 8 and 10 million barrels per day during the second quarter of 2020. Oil demand recovery has also been slower than expected, resulting in downward revisions to oil demand for almost every month from 2020 to 2022. Pre-virus demand levels are expected to be reached in mid-to-year-end 2022 (KAPSARC 2021).

Table 1. KAPSARC Oil Market Outlook (KOMO) supply/demand balance.

\begin{tabular}{l|c|c|c|c|c|c|c|c}
\multicolumn{1}{c|}{ MMB/d } & 1Q 2020 & 2Q 2020 & 3Q 2020 & 4Q 2020 & 1Q 2021 & 2Q 2021 & 3Q 2021 & 4Q 2021 \\
\hline A. Demand & 94.07 & 86.07 & 92.48 & 94.69 & 93.83 & 95.70 & 97.57 & 97.06 \\
\hline B. Supply & 100.71 & 92.45 & 90.93 & 92.91 & 93.38 & 94.23 & 95.65 & 96.33 \\
\hline Balance (B-A) & 6.64 & 6.38 & $(1.55)$ & $(1.78)$ & $(0.45)$ & $(1.47)$ & $(1.92)$ & $(0.73)$ \\
\hline OPEC+ Supply & 49.99 & 45.36 & 42.78 & 44.48 & 44.73 & 45.62 & 46.79 & 47.35 \\
\hline ROW Supply & 50.71 & 47.09 & 48.15 & 48.43 & 48.64 & 48.42 & 48.56 & 48.61
\end{tabular}

${ }^{*}$ ROW (Rest of the World).

\begin{tabular}{l|c|c|c|c}
\multicolumn{1}{c|}{ MMB/d } & 1Q 2022 & 2Q 2022 & 3Q 2022 & 4Q 2022 \\
\hline A. Demand & 98.28 & 98.86 & 100.40 & 100.65 \\
\hline B. Supply & 97.14 & 97.85 & 98.59 & 99.47 \\
\hline Balance (B-A) & $(1.14)$ & $(1.01)$ & $(1.81)$ & $(1.18)$ \\
\hline OPEC+ Supply & 47.87 & 48.34 & 48.78 & 49.40 \\
\hline ROW Supply & 48.71 & 48.95 & 49.16 & 49.37
\end{tabular}

* ROW (Rest of the World). 
Access to capital for shale producers is restricted as banks are concerned about the shale sector's profitability. Investors were losing patience over negative free cash flows generated by many shale developers. Operators are increasingly relying on internal cash flows to finance their operations, but they cannot compete with major producers who have enough of a financial cushion to survive the current economic turmoil.

Though large companies were late into the game, they have special departments focused on optimization, project design, and competitor intelligence. The growth of shale will come from large-scale development driven by big players.

The future growth prospects for the shale industry are clouded by the sentiment and forthcoming policies and regulations of the new U.S. administration. However, many operators may capitalize on higher oil prices, increasing the number of drilled and completed wells and placing them into production. 


\section{Innovation in the Shale Sector}

ignificant progress has been made in multi-stage fracking, underbalanced drilling, extended reach drilling, and artificial lift systems, which have helped improve initial productivities and optimize costs. In 2020, Simo fracks started to gain traction over conventional zipper fracks, as the former can produce significantly more footage fracked per day, and consequently lowers the cost per foot of the shale extracted. The technology spillover from other mature basins has helped developers in the Permian Basin to improve productivities. The average lateral length has improved significantly, as depicted in Figure 5 below.

Technology developers are working hard to strike the right balance between environmental, social acceptance, and profit factors. The year 2020 led to major structural improvements in the shale sector driven by falling costs in the industry. These improvements helped to accelerate the deployment of machine learning and artificial intelligence as a means of reducing risk and, henceforth, reducing development costs substantially. Future unconventional development will focus on deeper, tighter, more remote, and harder to extract hydrocarbon prospects. More technological innovation is underway to resolve some of the existing and emerging problems, including land-use footprint, gas flaring and venting, volumes of water usage, wastewater disposal, and water contamination.

Major industry/academia collaboration is underway, involving a range of operators (e.g., Saudi Aramco, Chevron, and Oxy) and universities (e.g., KFUPM, Colorado School of Mines and Texas A\&M University).

Figure 5. Average lateral length per well per completion year in the Permian Basin.

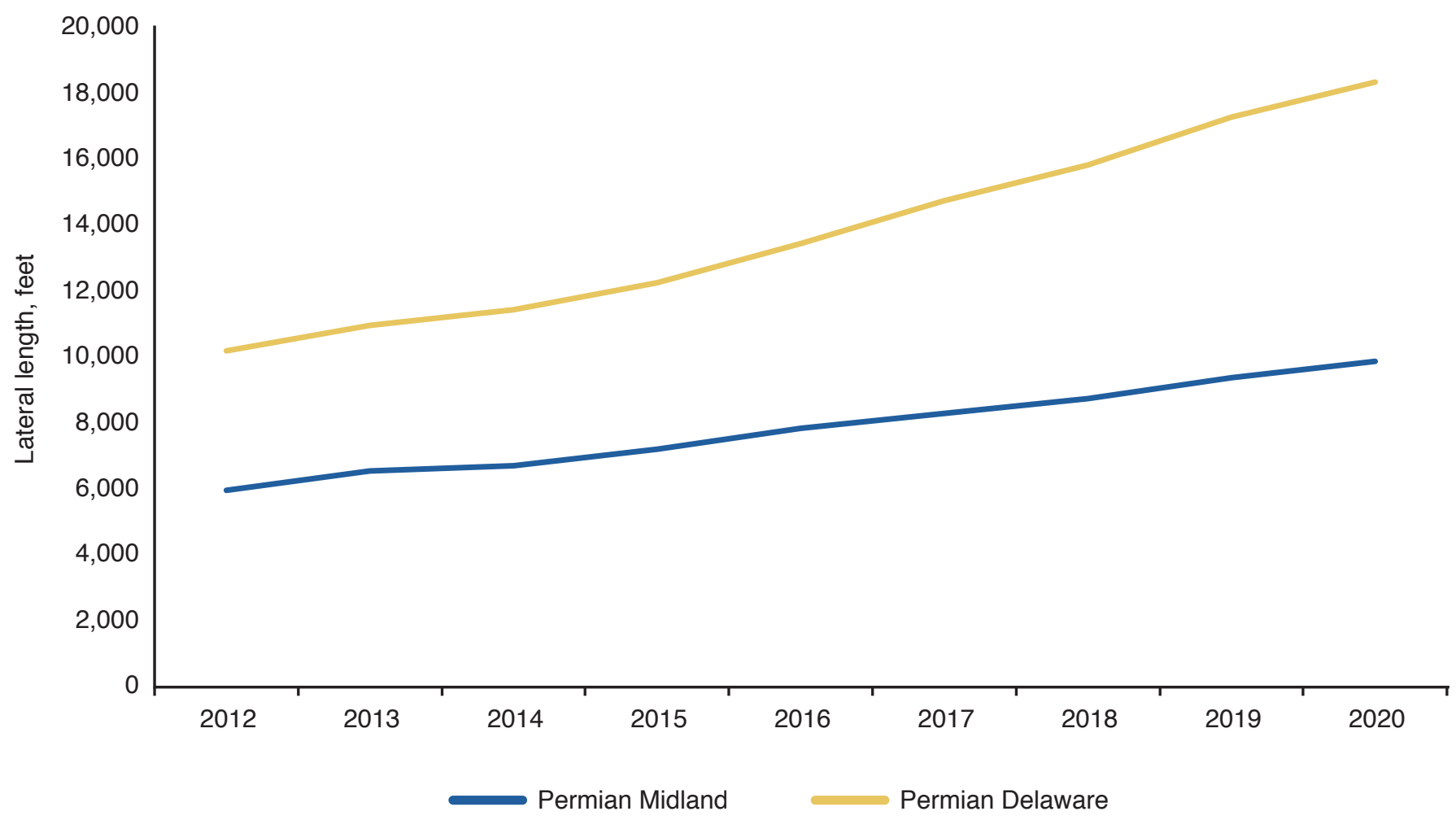

Source: Rystad Energy. 


\section{Shale Potential Outside North America}

There are vast resources of shale globally, spread over large areas. As of 2015, there were estimated to be 335 billion barrels of oil and 7,795 trillion cubic feet of technically recoverable gas worldwide, including in the U.S. (EIA 2015).

Many countries, such as Bulgaria and the United Kingdom, banned shale exploration and production because of environmental concerns related to water contamination and micro-seismic activities.

The success of the U.S. shale industry has encouraged many companies worldwide to exploit their shale assets. Many have initiated exploration and production programs to evaluate the feasibility of shale extraction through state-owned companies or in partnership with leading international oil and service companies. The technology spillover made available by many service companies, along with easy access to capital, and favorable regulatory environments, have helped these operators to commercialize their shale assets, as in the cases of Vaca Muerta in Argentina and Jafurah Basin in Saudi Arabia. The Saudi and Argentinan experiences were discussed in detail, as follows.

\section{Vaca Muerta play}

The development of Vaca Muerta in Argentina began in 2010. Production has increased over time, but the growth rates were not as aggressive as those of the U.S. shale sector. This was mainly due to the limited number of developers, both domestic and international, operating in Vaca Muerta. Technology spillover from the international developers helped to commercialize the basin and accelerate its development. Laterals are getting longer, and frack sand and fluid intensity are improving as producers get into full-scale development.
The development of Vaca Muerta faces many challenges associated with the end-market demand for its oil and gas. Major investments in the infrastructure and liquified natural gas (LNG) terminals are needed to boost growth in this basin. Drilling and completion activities were hit by the recent downturn. This is the same trend as that witnessed in the U.S. Depending on the price environment, operators can invest more in capex and restore growth in shale.

\section{Jafurah Basin}

Unlike Vaca Muerta, which enabled domestic and international operators to develop its unconventional assets, the development of unconventional assets in the Kingdom of Saudi Arabia is pioneered by the state-owned company, Saudi Aramco. Aramco has capitalized on many lessons the U.S. has learned from its shale gas development. It established an unconventional gas department to oversee the development of unconventional resources across the Kingdom, including tight sands and shale. The Jafurah Basin is one of the company's focus areas. The land area above the Jafurah Basin is approximately 17,000 square kilometers and is twice the size of Ghawar (Figure 6).

The basin offers condensate and ethane production. It contains significant volumes of condensates, making the exploitation of its tight oil economically viable. Aramco commercialized Jafurah by reducing the average well cost and increasing well productivity using directional drilling and multi-stage fracking. As with any shale or tight gas development, the extraction process for Jafurah requires significant volumes of water, which are derived from shallow aquifers. The company is experimenting with using seawater and treated sewage water to frack new wells. 
Figure 6. Jafurah Basin location.



Source: Saudi Aramco. 


\section{References}

U.S. Energy Information Administration (EIA). 2021. "Crude Oil and Natural Gas Drilling Activity." February 26. Accessed March 20, 2021. https://www.eia.gov/dnav/ng/ng_enr_drill_s1_m.htm.

- - - 2017. "Permian Basin oil production and resource assessments continue to increase." April 26. Accessed February 01, 2020. https://www.eia.gov/todayinenergy/detail.php?id=30952.

- - . 2015. "World Shale Resource Assessments." September 24. Accessed February 02, 2021. https:// www.eia.gov/analysis/studies/worldshalegas/.

KAPSARC. 2021. "KAPSARC Oil Market Outlook." February. 


\section{About the Workshop}

APSARC held a virtual workshop on

December 9 and 10, 2020, in partnership

with the Oxford Institute for Energy Studies and King Fahad University of Petroleum and Minerals. The workshop participants discussed the following topics to highlight opportunities and challenges faced by the global shale sector.

U.S. shale and the global oil market context

The financial health of the shale sector

Shale's potential outside North America

Dynamic innovation in the shale sector

The workshop gathered over 20 experts from various fields, including policy, research, investment, and the oil and gas industry.

\section{List of participants}

Abdelaziz Khlaifat - Professor of Petroleum Engineering, the American University of Cairo

Abdullah AI-Sultan - Dean of Research, KFUPM

Adam Sieminski - President, KAPSARC

Adi Imsirovic - Senior Research Fellow, OIES

Ahmed Fataierge - Supervisor, Saudi Aramco

Arterm Abramov - Head of Shale Research, Rystad Energy

Ayidh Al-Swadian - Frac Manager, Schlumberger
Bassam Fattouh - Director, OIES

Dongmei Chen - Research Fellow, KAPSARC

Fahad Alturki - VP Research, KAPSARC

Faris Alotaibi - Workshop Coordinator - KAPSARC

John Humphrey - Professor of Geosciences and Assistant Department Chair, KFUPM

Julio Arboleda - Research Fellow, KAPSARC

Kaushik Deb - Director of Markets and Industrial Development, KAPSARC

Kamel Bennaceur - CEO, Nomadia Energy Consulting

Khalid Al-Abdulqader - Executive Director of Unconventional Resources, Saudi Aramco

Lutz Kilian - Senior Economic Policy Advisor, Federal Reserve Bank of Dallas

Mine Yucel - Senior Vice President and Senior Research Advisor, Federal Reserve Bank of Dallas

Majed AI-Suwailem - Senior Research Associate, KAPSARC

Malik Selemankhel - Senior Research Associate, KAPSARC

Paul Sullivan - Professor at NDU Johns Hopkins

Rami Shabaneh - Senior Research Associate, KAPSARC

Trisha Curtis - Founder and CEO, PetroNerds

Walid Matar - Research Fellow, KAPSARC 


\section{Notes}

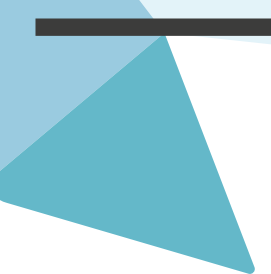


Notes

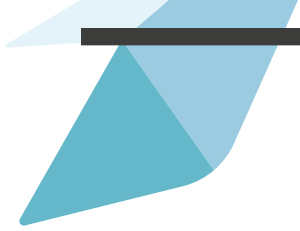




\section{About the Team}

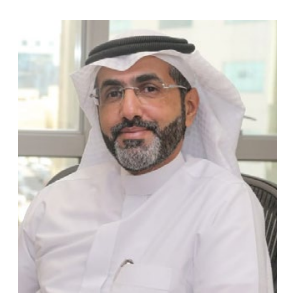

\section{Fahad Alturki}

Dr. Fahad Alturki is Vice President of Research at King Abdullah Petroleum Studies and Research Center (KAPSARC). In this role, he oversees KAPSARC's research programs and priorities, ensuring that these are strategically focused on impacts within the Kingdom of Saudi Arabia. Dr. Fahad interacts with key stakeholder groups within the Kingdom and internationally in the private, academic, and government sectors. Moreover, he is responsible for setting the overall directions and parameters for collaboration with KAPSARC's partners and affiliates.

Prior to joining KAPSARC, Dr. Fahad was the chief economist and head of research at Jadwa Investment Company in Riyadh, where he managed the economic research department and published regular reports on issues related to the Saudi and global economies and the world oil market. He was also the chairperson of the Public Funds Board, a board member of the Jadwa REIT AI Haramain Fund and Jadwa REIT Saudi Fund, and a member of Jadwa's executive management committee.

Dr. Fahad has a proven track record in economics, with more than 20 years of experience in the field. Before joining Jadwa, Dr. Fahad was the chief economist at Barclays, Saudi Arabia. Prior to his time at Barclays, Dr. Fahad was an economic specialist at the Saudi Arabian Monetary Authority, where he worked for 11 years in the Economic Research and Statistics Department. Dr. Fahad has also worked as an economist at the Middle East and Central Asia Department of the International Monetary Fund.

Dr. Fahad holds a B.A. in Business Administration from King Saud University in Saudi Arabia and master's and Ph.D. degrees in economics from the University of Oregon (Eugene, United States).

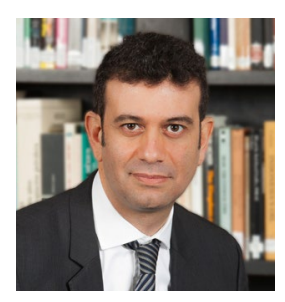

\section{Bassam Fattouh}

Dr. Bassam Fattouh is the Director of the Oxford Institute for Energy Studies (OIES) and Professor at the School of Oriental and African Studies (SOAS). He has published a variety of articles on energy policy, the international oil pricing system, OPEC behavior, the energy transition, and the economies of oil-producing countries. Dr. Fattouh served as a member of an independent expert group established to provide recommendations to the 12th International Energy Forum (IEF) Ministerial Meeting in Cancun (29-31 March, 2010) for strengthening the architecture of the producer-consumer dialogue through the IEF and reducing energy market volatility. He is the recipient of the 2018 OPEC Award for Research. $\mathrm{He}$ acts as an advisor to a number of governments and companies. He is a regular speaker at international conferences. 




\section{Kaushik Deb}

Kaushik is an applied economist and a research fellow at KAPSARC. He is currently responsible for defining and operationalizing the research agenda for KAPSARC's Markets and Industrial Development team. Kaushik was previously the head of global gas markets in the Group Economics team at BP, where he oversaw the analysis that formed the basis for BP's natural gas investment and trading strategy. Before BP, Kaushik worked at IDFC Bank, where his portfolio included policy research and advocacy on infrastructure and environmental economics issues. These issues included low-carbon infrastructure, decentralized electricity services in rural areas, and organized intermediate public transport systems for small towns. Kaushik holds a doctor of sciences (D.Sc.) degree from ETH Zurich. He has also guided and implemented research in applied economics at TERI University, India, where he was also the program director of its two MBA programs.

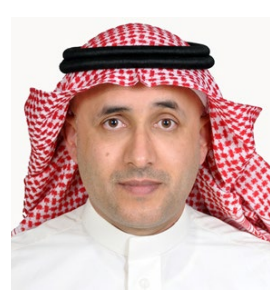

\section{Abdullah Sultan}

Dr. Sultan is an Associate Professor in the Department of Petroleum Engineering. His research group focuses on complex and reactive fluids to address problems in the oil and gas industry with a focus on enhanced oil/gas recovery, drilling fluids, well stimulation, gel, emulsions, and flow assurance. He established the Complex and Reactive Fluids (CRF) Lab at KFUPM. Dr. Sultan has numerous publications in refereed journals and conferences. He served as Director for the Center of Petroleum and Minerals, Research Institute at KFUPM (2010 - 2015), and Chairman for the Department of Petroleum Engineering (2012 - 2017).

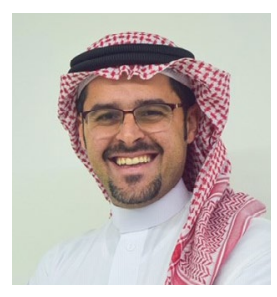

\section{Majed AI-Suwailem}

Majed is a senior research associate at KAPSARC who focuses on sustainable energy, energy security and energy infrastructure. He has over 15 years of experience in the oil and gas industry at Chevron and Saudi Aramco. His industry experience includes simulation and modeling, subsurface asset management, hydrocarbon reserves estimation, disruptive technologies, and business planning.

Majed holds a B.Sc. degree in petroleum engineering from the University of Tulsa in the U.S. He also holds an M.Eng. degree in petroleum engineering from Texas A\&M University and an M.Sc. in reservoir geosciences and engineering from the Institut Francais du Petrole (IFP School). 


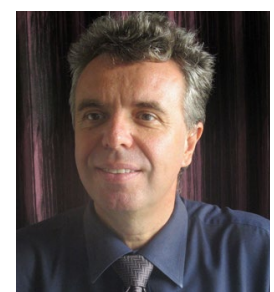

\section{Adi Imsirovic}

Adi Imsirovic has over 30 years of experience in oil trading. He held a number of senior positions, including Global Head of Oil at Gazprom Marketing and Trading, Director of Petraco and the Head of their Singapore office and the Regional Manager of Texaco Oil Trading for Asia.

Adi also taught economics at Surrey University for several years - Energy Economics and Resource and Environmental Economics. He has written several papers and articles on oil and gas prices, benchmarks and energy security.

He has an honors degree (B.Sc.) in Economics and a Master of Science (M.Sc.) degree in Energy Economics from Surrey University. He was also a Fulbright Scholar and studied at the Graduate School of Arts and Sciences, Harvard University.

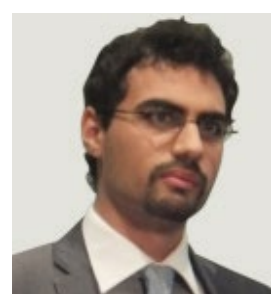

\section{Walid Matar}

Walid is a research fellow at KAPSARC developing energy systems models, including the KAPSARC Energy Model, and satellite projects such as the residential electricity use model. Walid holds a Master of Science degree in mechanical engineering from North Carolina State University, and a Bachelor of Science degree in the same field from the University of South Carolina.



\section{Malik Selemankhel}

Malik is a senior research associate in the Markets and Industrial Development team focused on downstream refining and petrochemical value chains. He was a professional engineer in Canada with over 10 years of both office- and field-based engineering and oil business experience. Malik has experience in the upstream, midstream and downstream sectors of North America's oil and gas industry. He has a keen interest in integrated hydrocarbon value chain optimization to help oil and gas companies maximize their profits. Malik's research interests include the optimization of integrated value chains driven by regional and international regulations on fuels and emissions, and economic growth, among other factors. 


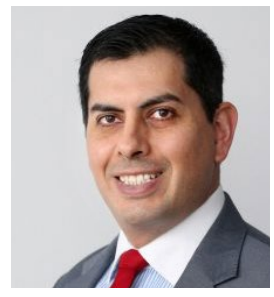

\section{Julio Arboleda}

Julio is an economist and civil engineer with over 18 years of experience in the oil and gas field. He has worked on energy policy and data analysis for international organizations, governmental advisory services, and the construction of energy projects. Julio has participated as a senior energy consultant within organizations, including OPEC and KAPSARC. During his position as Energy Policy Analyst in OPEC, he was one of the major contributors to the OPEC World Oil Outlook (WOO) for over seven years. His experience at governmental and private-sector levels, in the field and the office, allows him to understand research dynamics in the energy sector.

\section{About the Project}

The Future of Shale Development project aims to assess the impact of U.S. shale oil and gas on supply and demand balances. With a time series of available production data, we, at KAPSARC, investigate the drivers (both below and above ground) of the successful growth of the U.S. shale industry thus far. We consider these drivers in retrospect and analyze in detail whether these mechanisms are sustainable going forward.

This project also examines the performance of U.S. shale production. We highlight challenges that may hinder or contribute to shale oil and gas growth, including technologies, environmental policies, and companies' access to capital. 
INAPSARC

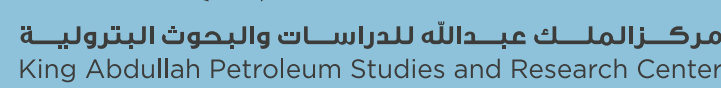

www.kapsarc.org 